\title{
PENGEMBANGAN PROTOTIPE SEKOLAH PINTAR: UANG SAKU ELEKTRONIK
}

\author{
Ilyas Nuryasin'), Dwi Arif Al-Mubarok ${ }^{2)}$, Abdul Qhodir Zaelany ${ }^{3)}$ \\ 1,2,3 Program Studi Informatika, Fakultas Teknik, Universitas Muhammadiyah Malang \\ Jl. Raya Tlogomas No. 246 Malang \\ Co Responden Email: ilyas@umm.ac.id
}

Article history

Received April 02, 2021

Revised June 06, 2021

Accepted June 16, 2021

Available online June 20, 2021

Keywords

Smart School,

E money,

$R F I D$

Riwayat

Diterima 02 April 2021

Revisi 06 Juni 2021

Disetujui 16 Juni 2021

Terbit 20 Juni 2021

Kata Kunci

Sekolah Pintar,

Uang Saku Elektronik, RFID

\begin{abstract}
The concept of smart objects is increasingly being adopted by the public, such as smart cities, smart agricultures, smart campuses, smart schools and so on. This study aims to develop a smart school by developing the prototype of smartcard-based student allowance system. This research is conducted with research and development methods, by starting with a scientific study and then continuing with drafting a requirement analysis, designing, implementing and testing the prototype. This prototype offers management of student allowances that they spend in a school environment that is integrated with smartcards. This prototype has been tested and is running according to its function.
\end{abstract}

\begin{abstract}
Abstrak
Konsep smart object semakin banyak diadopsi oleh masyarakat, seperti kota pintar, pertanian pintar, kampus pintar, school pintar dan lain sebagainya. Penelitian ini bertujuan untuk mengembangkan sekolah pintar dengan mengembangkan prototipe sistem tunjangan siswa berbasis kartu pintar. Penelitian ini dilakukan dengan metode penelitian dan pengembangan, dimulai dengan studi ilmiah kemudian dilanjutkan dengan penyusunan analisis kebutuhan, perancangan, implementasi dan pengujian prototipe. Prototipe ini menawarkan pengelolaan uang saku siswa yang mereka belanjakan di lingkungan sekolah yang terintegrasi dengan kartu pintar. Prototipe ini sudah diuji fungsionalitasnya dan berjalan sesuai fungsinya.
\end{abstract}

\section{PENDAHULUAN}

Sekolah wajib dua belas tahun yang dicanangkan pemerintah memberikan akses bagi seluruh putra putri bangsa pada usia sekolah untuk bisa mengenyam pendidikan. Pada usia ini mereka mengukir keilmuan dan mematangkan pikiran dan kebijaksanaan. Hal inipun menjadi perhatian semua pihak, sehingga menjadi program hidup masingmasing keluarga. Berdasarkan data Badan Pusat Statistik (BPS), lebih dari 70\% masyarakat usia 7-24 tahun yang mendapat akses sekolah (BPS, 2020).

Program ini perlu didukung oleh semua pihak agak semua mendapatkan akses pendidikan. Pihak yang paling bertanggungjawab dalam pendidikan anak adalah orangtua. Mereka memiliki wewenang untuk mengarahkan putra-putrinya dalam menuntut ilmu. Mereka memiliki strategi khusus agar mereka bersemangat dalam belajar. Salah satunya adalah dengan memberikan dukungan finansial untuk dibelanjakan di lingkungan sekolah. Selain itu, menurut Perencana Keuangan Tatadana Consulting, Diana Sandjaja, pemberian uang saku adalah untuk melatih anak mengelola uangnya serta mengambil keputusan terkait keuangannya sendiri (Arief \& Prasetyo, 2016).

Beragam cara orangtua memberikan kepercayaan kepada putra-putrinya dalam mengelola uang saku, seperti harian, pekanan dan bahkan bulanan. Sebagian orangtua memberikan akses penuh keuangan kepada putra-putrinya, namun ada pula yang 
membatasi keuangan mereka dengan berbagai alasan. Salah satu alasan karena mereka belum mampu mengelola keuangann sendiri. Sebagian dari mereka sudah menghabiskan uang saku sebelum periode uang saku mereka berakhir. Dalam hal ini seperti yang disampaikan Perencana Keuangan Janus Financial, Dwita Ariani, orang tua memiliki tugas untuk membantu proses pendewasaan anak menghadapi uang (Arief \& Prasetyo, 2016).

Oleh karena itu perlu adanya kontrol dari orang tua dengan mengetahui pengeluaran putra-putrinya pada saat sekolah. Penelitian ini mengusulkan sebuah prototipe untuk mengelola uang saku siswa yang mereka belanjakan di lingkungan sekolah. Prototipe ini diintegrasikan dengan sistem pelaporan keuangan untuk mengetahui pengeluaran siswa menggunakan kartu pintar.

Uang elektronik dalam bentuk kartu pintar semakin memasyarakat. Berdasarkan laporan Bank Indonesia, jumlah uang elektronik yang beredar mencapai (BI, 2020a) dengan nomimal lebih dari 22 trilyun rupiah (BI, 2020c). Bahkan Bank Indonesia saat inipun terus memperkuat dan memperluas implementasi elektronifikasi dan digitalisasi (BI, 2020b).

\section{KAJIAN LITERATUR}

Pemanfaatan smartcard dalam banyak keperluan telah dibahas bahkan diimplentasikan dalam berbagai bentuk. Seperti pemanfaatan uang elektronik, tol elektronik, sistem parkir dan lain sebagainya. Smartcard adalah sebuah chips yang memnafaatkan teknologi nirkabel untuk melakukan transfer data. Smartcard menggunakan teknologi Radio Frekuensi Indetification (RFID). Terdapat 3 jenis RFID, yatu RFID aktif dan pasif dan semi-pasif (Clinten, 2019). RFID aktif adalah RFID yang memiliki sumber daya sendiri dari baterai dan RFID pasif tidak memiliki baterai, namun diaktifkan dari pembaca (FDA, 2018). Adapun RFIS Semi-pasif adalah RFID yang memiliki baterai namun tidak memancarkan sinyal hingga pembaca RFID mentransmisikan terlebih dahulu (Printgraphicmagz.com, 2020).

Selain itu, teknologi yang juga menggunakan frekuensi radio adalah NFC atau Near Field Communication. NFC merupakan teknologi chip yang memiliki kemampun mentransmisikan gelombang pada $13,56 \mathrm{MHz}$ yang dapat membaca tag pada sikuit pasif (Arcese et al., 2014). Umumnya konektivitas untuk NFC adalah komunikasi dengan jarak pendek, sehingga sering terlihat saling tertempel.

Keunggulan dari teknologi NFC adalah sedikit interferensi gelombang oleh perangkat lain. Hal ini disebabkan karena sangat dekatnya kontak antar piranti. Keunggulan ini dapat dimanfaatkan untuk bordered area access, seperti pembayaran tunggal, autentikasi dan keperluan lain yang memiliki area pembacaan yang terbatas. Selain itu, teknologi transfer data menggunakan NFC mengurangi risiko pembobolan data oleh pembobol karena area interaksinya terbatas, sehingga tingkat keamanan lebih tinggi dibanding protokol nirkabel lain (NFCFORUM, 2021).

Penelitian ini berfokus pada pengembangan prototipe sekolah pintar dengan pembahasan pemanfaatan smartcard dalam bentuk uang saku elektronik. Sekolah pintar adalah sebuah konsep pengelolaan sekolah secara elektronik yang meliputi kegiatan belajar-mengajar dan administrasi sekolah(Arthana et al., 2018). Prototipe ini menawarkan fitur-fitur yang mewakili fungsi dasar integrasi sistem point of sales menggunakan smartcard dan pelaporannya.

\section{METODE PENELITIAN}

Penelitian ini dikembangkan menggunakan pendekatan Research and Development. Kajian ilmiah terhadap teknologi terkini dilakukan terlebih dahulu dengan mengumpulkan sumber-sumber informasi yang selanjutnya ditelaah. Selanjutnya tahapan pengembangan sistem dilakukan dengan melakukan analisis untuk menghasilkan kebutuhan sistem, baik berupa hardware maupun software. Sistem ini memiliki 3 pengguna, yaitu administratur, kasir dan siswa.

Adapun modul aplikasi yang ingin dikembangkan antara lain modul pengelolaan barang, karyawan, pelanggan, suplier. Selain itu, prototipe ini juga menawarkan fungsi transaksi, mutasi barang, laporan, penjualan, topup saldo dan validasi pembayaran.

Adapun gambaran umum aplikasi kami deskrispsikan dalam bentuk usecase berikut: 


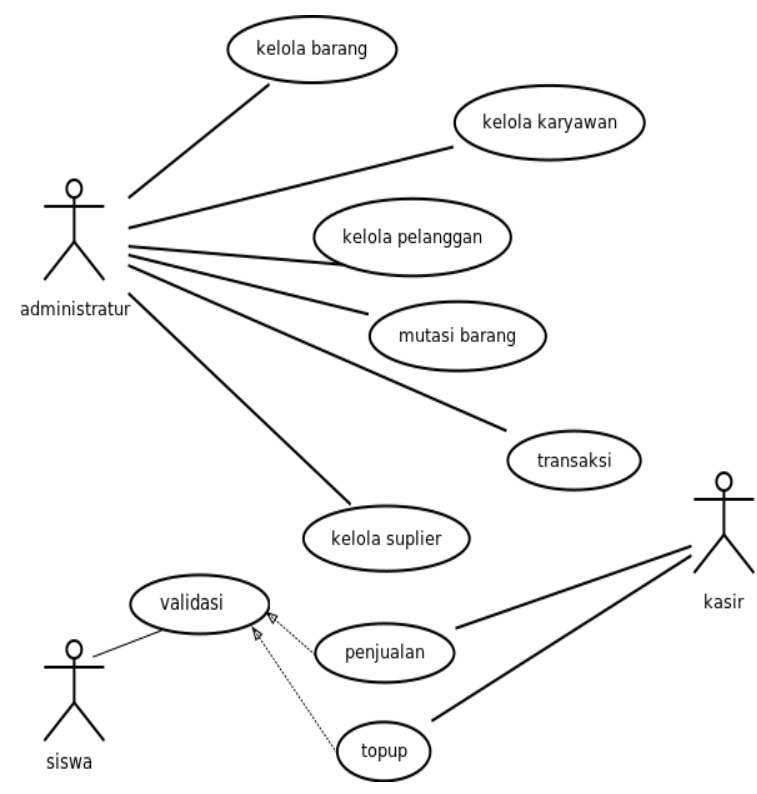

Gambar 1. Usecase diagram aplikasi

Tahapan selanjutnya adalah melakukan perancangan. Perancangan dilakukan dengan cara melakukan perancangan pada proses bisnis, data, dan antarmuka. Sistem ini membutuhkan perangkat keras seperti tag dan pembaca tag RFID. Selai itu sistem membutuhkan pembaca kode bar untuk mengelola barang. Selanjutnya, dari rancangan yang telah disusun kemudian diimplementasikan dalam bentuk website menggunakan bahasa pemrograman PHP dan duiji fungsionalitasnya.

\section{HASIL DAN PEMBAHASAN}

\section{A Transaksi Pembelian Siswa}

Modul transaksi pembelian digunakan untuk melakukan pendataan dan penjualan barang. Barang yang disediakan pada etalase kantin diatur secara swalayan yang kemudian didata oleh kasir.

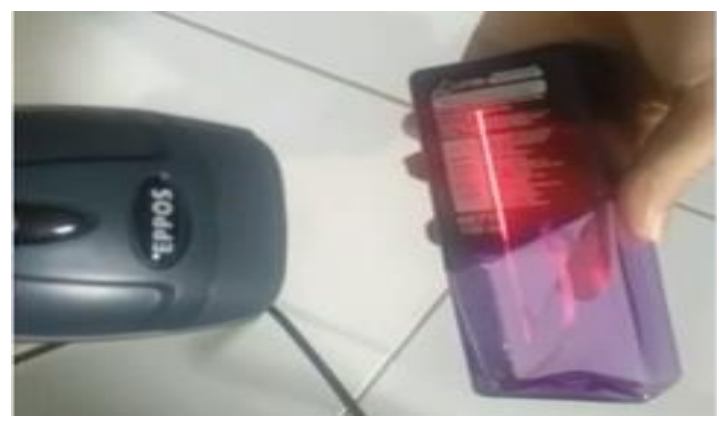

Gambar 2. Pembacaan barang menggunakan barcode reader

Setelah melakukan pendataan barang, maka kasir akan menghimpun belanjaan dan mengetahui total pembelian yang dilakukan oleh siswa. Untuk melakukan kontrol jajan, maka sistem memberlakukan pemeriksaan saldo uang saku yang terdapat pada tag yang bisa dirupakan dalam bentuk kartu pelajar.

Siswa memindai kartu pelajar (tag RFID) pada reader yang disediakan pada meja kasir. Selanjutya kasir dan siswa mengetahui jumlah saldo yang terdapat pada kartu. Apabila mencukupi, siswa dapat melanjutkan transaksi. Namun apabila tidak maka siswa tidak bisa melanjutkan transaski san diminta untuk melakukan pengisisan saldo.

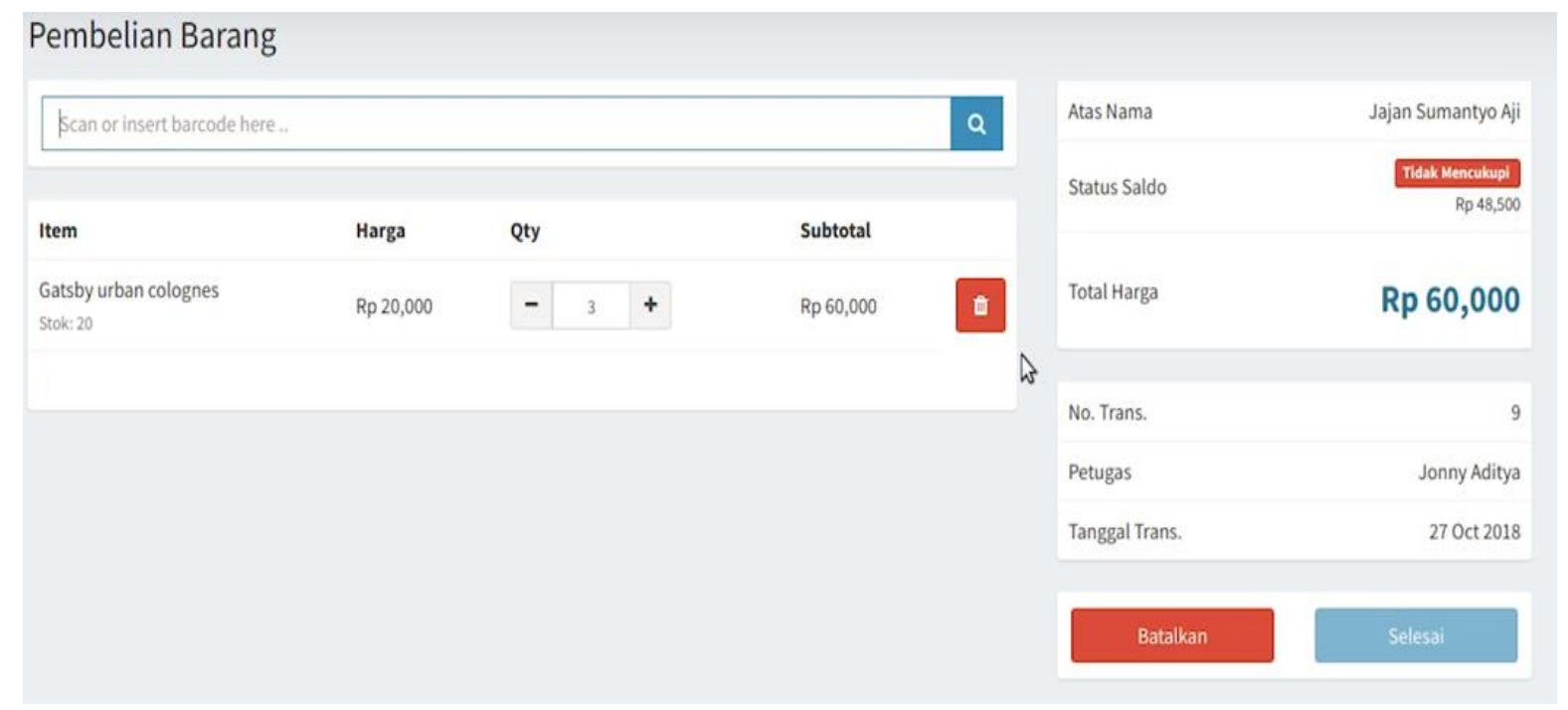

Gambar 3. Pemeriksaan saldo siswa 
Tahapan terakhir dari proses transaksi ini adalah siswa melakukan validasi atas transaksi yang telah dilakukan. Validasi ini digunakan untuk menjamin bahwa pemilik kartu adalah orang yang benar atau orang yang diberi akses untuk menggunakan kartu itu. Tujuan lain dari validasi ini adalah untuk mengurangi tindak penyalahgunakan kartu oleh orang yang tidak berhak.

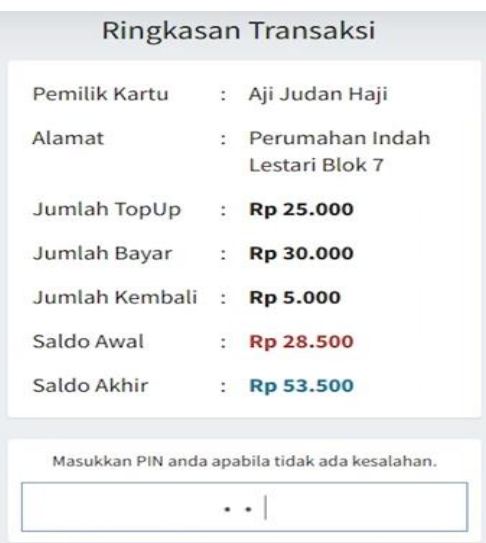

Komfirmasi Pembelian

Gambar 4. Validasi transaksi

\section{B Pengisian Saldo Kartu}

Siswa dapat melakukan penambahan saldo pada kartunya masing-masing. Penambahan saldo dapat dilakaukan pada kasir dengna melakukan pemindaian kartu pada pembaca RFID. Selanjutnya, siswa diminta melakukan validasi dengan mengisikan nomor PIN yang benar.

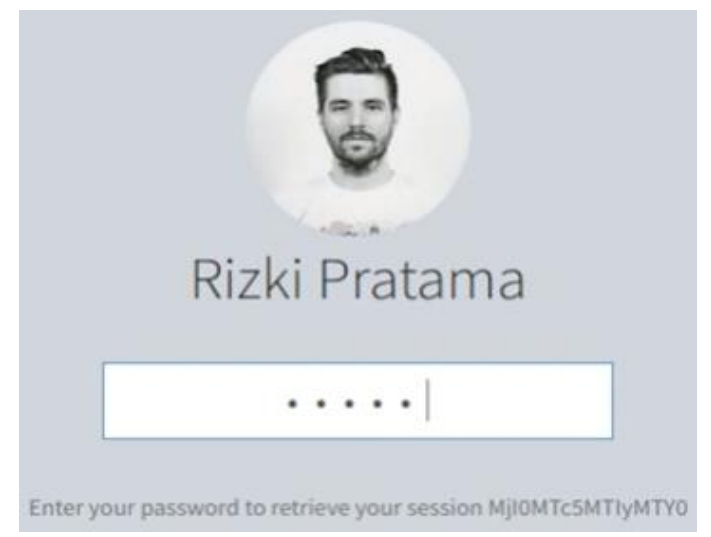

Gambar 5. Validasi TOP-UP

Petugas kasir akan melakukan pemeriksaan dan mengisi dengan besaran saldo yang ingin disetorkan oleh siswa. Pengisian hanya dilakukan pada depo kantin dengan perangkat yang disambungkan pada mesin kasir.

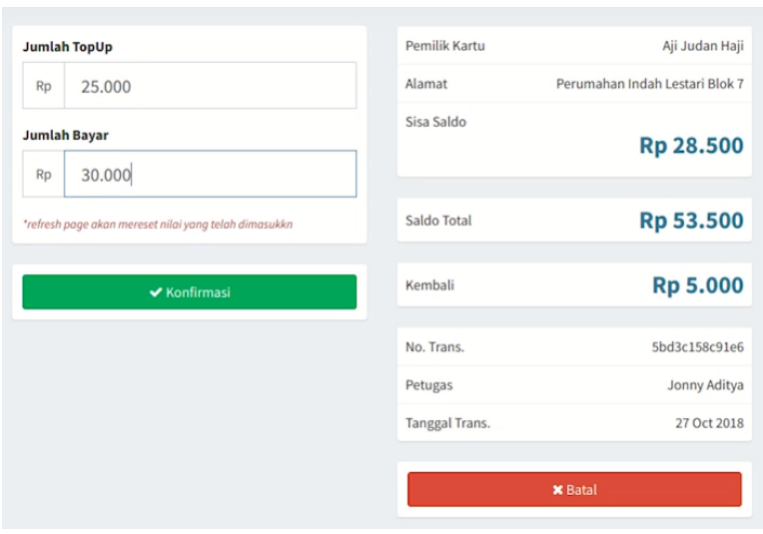

Gambar 6. Pengisian saldo

\section{Laporan Keuangan}

Pada bagian ini, setiap transaksi akan disimpan pada sistem sesuai dengan pengguaan kartu. Laporan ini selanjutnya dapat disampaikan kepada orang tua siswa sebagai laporan dan evaluasi untuk pemberian uang saku siswa.

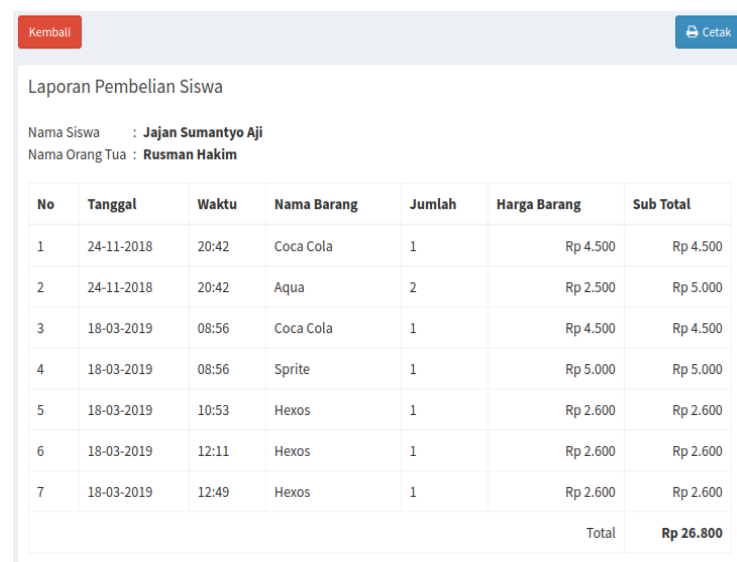

Gambar 7. Laporan keuangan siswa

\section{Diskusi}

Prototipe aplikasi manajemen uang saku siswa telah dikembangkan dengan fungsi dasar pengelolaan uang digital pada kantin sekolah. Penelitian ini sifatnya terbatas untuk lingkungan tertentu dengan model pembayaran yang disepakati oleh lingkungan tertentu. Dengan semakin maraknya transaksi menggunakan uang elektronik, maka penulis optimis bawa intgrasi dengan penyedia uang elektronik lain dapat diintegrasikan Berdasarkan pantauan Otoritas Jasa Keuangan (OJK), pada akhir tahun 2020 terdapat 149 penyelenggara fintech terdaftar dengan 
anggota terdaftar lebih dari 248 juta akun (OJK, 2021).

Selain itu, metode pelaporan pada sistem ini sifatnya adalah laporan transaski yang akan dilaporkan pada saat rapat dengan orangtua, seperti pengambilan raport atau momentum lain pada saat bertemu dengan orangtua. Penelitian selanjutnya dapat dikembangkan metode pelaporan waktu nyata pada platform website, sehingga orangtua dapat secara langsung melalukan pemantauan terhadap uang saku putra-putrinya.

\section{KESIMPULAN}

Prototipe ini menawarkan pengelolaan uang saku siswa yang mereka belanjakan di lingkungan sekolah menggunakan smartcard yang diintegrasikan dengan sistem pelaporan keuangan. Prototipe ini mencoba mengakomodasi beberapa fungsi dasar, seperti point of sales, layanan topup dan pelaporan. Prototipe ini telah diuji dan berjalan sesuai dengan fungsinya.

\section{REFRENSI}

Arcese, G., Campagna, G., Flammini, S., \& Martucci, O. (2014). Near Field Communication: Technology and Market Trends. Technologies, 2(3), 143-163. https://doi.org/10.3390/technologies2030 143

Arief, A. M., \& Prasetyo, H. (2016). Ingat, uang saku anak bukan sekadar uang jajan. Kontan.Co.Id. https://personalfinance.kontan.co.id/new s/ingat-uang-saku-anak-bukan-sekadaruang-jajan

Arthana, I. K. R., Dantes, G. R., \& Dantes, N. (2018). Optimalisasi pemanfaatan teknologi informasi dan komunikasi (tik) dalam bidang pendidikan melalui penerapan smart school. Jurnal Widya Laksana, $\quad 7(1), \quad 81-91$. https://ejournal.undiksha.ac.id/index.php /JPKM/issue/view/775

BI. (2020a). Jumlah Uang Elektronik Beredar. https://www.bi.go.id/id/statistik/ekonomi -keuangan/ssp/uang-elektronikjumlah.aspx
BI. (2020b). Tinjauan Kebijakan Moneter Desember 2020. https://www.bi.go.id/id/publikasi/lapora n/Pages/Tinjauan-Kebijakan-MoneterDesember-2020.aspx

BI. (2020c). Transaksi Uang Elektronik. https://www.bi.go.id/id/statistik/ekonomi -keuangan/ssp/uang-elektroniktransaksi.aspx

BPS. (2020). Persentase Penduduk Usia 7-24 Tahun Menurut Jenis Kelamin, Kelompok Usia, dan Partisipasi Sekolah Tahun 2002-2015.

BPS.Go.Id. https://www.bps.go.id/statictable/2014/0 9/05/1533/persentase-penduduk-usia-7-

24-tahun-menurut-jenis-kelaminkelompok-umur-sekolah-dan-partisipasisekolah-1-2002-2020.html

Clinten, B. (2019). Mengenal Teknologi RFID di E-KTP dan Kartu Uang Elektronik. Kompas.Com.

https://tekno.kompas.com/read/2019/04/ 29/07050057/mengenal-teknologi-rfiddi-e-ktp-dan-kartu-uangelektronik?page $=$ all

FDA. (2018). Radio Frequency Identification (RFID). https://www.fda.gov/radiationemitting-products/electromagneticcompatibility-emc/radio-frequencyidentification-rfid

NFC-FORUM. (2021). NFC Technology. https://nfc-forum.org/what-is-nfc/aboutthe-technology/

OJK. (2021). Statistik Fintech Lending Periode Desember 2020.

Printgraphicmagz.com. (2020). RFID. Teknologi Dan Beragam Aplikasinya di Industri Cetak - Print Graphic Magazine. http://www.printgraphicmagz.com/2020/ 05/08/rfid-teknologi-dan-beragamaplikasinya-di-industri-cetak 